\title{
Information Systems Values: A Study of the Intranet in Three French Higher Education Institutions
}

\author{
Philippe Cohard \\ University of Montpellier, MRM, France \\ Labex Entreprendre, Institut Montpellier Management, France \\ philippe.cohard@umontpellier.fr \\ DOI: 10.34190/EJISE.20.23.1.010
}

\begin{abstract}
Evaluation of performance of the Information System (IS) function has long been a concern of senior management in organisations. The IS function can impact competitive advantage which is why executives regularly look for evidence of returns on IT investments. The paper reports on a study which investigated how patrimonial value (inherent or actual quality of hardware, software and know-how) and use value (contribution to the business) influence the success and organisational impact of an intranet. This paper proposes a set of principles for the conduct and implementation of analysis of these two intangible values of IS function. Research was conducted in three field studies of business and engineering schools in France. The data collected in questionnaires were analysed using the PLS structural equation method. This research provides theoretical contributions with a model giving a deeper comprehension of patrimonial value and use value of information systems, as well as explaining the relationships between these two values, success and organisational impact.
\end{abstract}

Keywords: Information system values, intangible value, evaluation, intranet, structural equation modelling, Partial Least Squares

\section{Introduction}

Evaluation of the performance of Information System (IS) function has long been a concern of information systems management in organisations. The IS could provide a competitive advantage (Nevo and Wade, 2010), and it is why executives regularly look for evidence of returns on IT investments. Indeed, lots of managers question the contribution to the value of their intranet, their ERP, their cloud, etc. This article presents analysis of IS values as an alternative view to previous approaches as proposed by a large number of models, the measurements of which barely take into account the values created by the IS. Intangible assets and values are actual research subjects of concern, specifically related to technologies and MIS (Erickson and Rothberg, 2019; Wataya and Shaw, 2019; Saunders and Brynjolfsson, 2016). Moreover, these approaches cannot be aggregated in a meaningful way, being limited to identifying sources of performance or non-performance (Chang and King, 2005). IS value analysis globally considers the assets of the organisation (Marciniak and Rowe, 2009), by integrating the intangible values of the IS. Two levels of analysis can be identified. The first level is endogenous and concerns the patrimonial and use values of the IS. The second level of analysis, exchange value, is exogenous and concerns the exchange of information with the outside of the organisation. Understanding the relation between patrimonial value and use value is a necessary precursor to the examination of the exogenous level. This is why we focus in this article on the endogenous level, the characterization and the analysis of relations between the patrimonial value and the use value. If organisations do not benefit from information technologies in the same way (Saunders and Brynjolfsson, 2016), it will be interesting to understand why, looking from within the organisation. Therefore, we ask about these values: how do patrimonial and use values influence the success and the organisational impact of an intranet? This article is our answer to this question; it proposes a set of principles for the conduct and implementation of IS value analysis.

It is to be noted that the proposed evaluations can be considered to belong to the generation of the judgment in the generations of Guba and Lincoln (1989).

In order to answer this question, in the second part, we analyse the explanation of the theoretical bases, including a review of the literature mobilising the framework of analysis of IS research schools of thought proposed by Chang and King (2005), and we study the concepts of functional values of the IS. In the third part, we present the methodological bases of the study, our hypotheses and our research model. In the fourth part we discuss selection of the PLS methodology for processing the data. Then in the fifth part, we present analysis of the processed data and outcomes. The sixth part discusses results of the analysis including our conclusions Higher Education Institutions. The Electronic Journal of Information Systems Evaluation, 23(1), pp. 150-167, available online at www.ejise.com 
on the contributions of our research. Finally, in the seventh part, we explain the limits and the future of the research.

\section{Literature review}

The ability to improve organisational performance through IT requires the implementation of an effective IS that includes hardware, software, associated services (provided by its function and IT management) as well as organisational capabilities. Chang and King (2005) categorized the different streams of research according to whether they address capabilities, effectiveness and success, service quality, functional evaluation, or subfunctional evaluation of the information system. So, we analysed the literature that supported the classification developed by Chang and King (2005). We then transposed the literature on intranets into this classification. This allowed us to position our own research and accurately identify the gap it fills and to anchor our field of study. Then, in a second step, from the studied literature we proposed a questionnaire tool and proceeded to its evaluation. The developed tool informs us about the users' perceived value of the IS function (patrimonial values, use value) in which we are interested.

\subsection{IS capability}

The capability of the IS arises from an assembly of hardware, software, staff and process that is used to translate financial investments into IS in terms of business performance. The existence of links between IT capability and performance was studied by Santhanam and Hartono (2003) on the basis of statistical and financial indicators. Their results indicate that firms with higher IT capability perform above the industry average. In addition, stock market value can be positively influenced by the communication of IT infrastructure investment plans (Chatterjee, Pacini and Sambamurthy, 2002). That can be particularly true for intranet (important infrastructure investment for organisations) as it offers a potential solution to problems of internal communication and access to information. However, it also raises questions on the effectiveness of applications (Balasubramanian, Kulatilaka and Storck, 2000). The question of the benefit provided by computer-mediated communication has been studied by Andersen $(2001 ; 2005)$. Andersen showed that there is a significant and positive relationship between computer-mediated communication and the firm profitability. In the MIS Quarterly review, Saunders and Brynjolfsson (2016) showed through an econometric method on a panel of 127 firms, that IT intangible assets are significant drivers of market value although they do not appear in the accounts. The analysis of Saunders and Brynjolfsson (2016, p.83), indicate that : "IT is not a rising tide that lifts all boats".

\subsection{Effectiveness or success of the IS}

In 1992, Delone and McLean developed their Information Systems Success Model (ISSM). This ISSM model has been tested by numerous empirical studies. Several authors have applied it to intranets (Mosbey, Baile and Zeribi 2012; Klecun and Cornford, 2003). In their article Mosbey, Baile and Zeribi (2012) proposed to evaluate the perceived success of an intranet used in the banking sector by an ex-post evaluation. They empirically showed that perceived success of the intranet is influenced, on the one hand, by technical, social and organisational determinants and on the other, by determinants of the user acceptance process of the intranet. In their case study, Klecun and Cornford (2003) performed an interpretative evaluation of an intranet for healthcare at a hospital. In this study the authors aim to check which applications are used, for which purpose and to what extent they are perceived as beneficial to the practice. To do so, the evaluation (Klecun and Cornford, 2003, p.414) takes into account “the six major categories that are included in DeLone and McLean's [1992] taxonomy". Klecun and Cornford (2003) concluded that generally respondents have a positive attitude towards the system and its evaluation. A majority of them expressed the need for the intranet to be integrated into the health care system. All users agree that the more applications come available on the intranet, the more it will be perceived as useful (Klecun and Cornford, 2003).

Based on all the studies carried out and in response to criticisms and suggestions (Petter, Delone, and McLean, 2008), Delone and McLean (2003) proposed a second model. They modified their model and in particular added the quality of service dimension, which is the subject of the following section. The field of research on effectiveness or success of IS has developed because IS have common criteria which can be evaluated (judgment) and make it possible to determine which IS is successful and which is not. More recently, Petter, Delone and Mclean (2013) questioned the independent variables that make the IS successful. By a qualitative review of the literature on 140 studies, Petter, Delone and Mclean (2013) identified 43 variables determining the success of the IS. Then they grouped them into five categories of Leavitt's model (task, user, social, project and organisation characteristics). Thus Petter, Delone and Mclean (2013) have identified the important success factors that 
through many studies have regularly been associated with the success of the IS. Effectiveness or success is a fertile field of research in information systems. While effectiveness or success can be measured at a point in time, as explained by Saxena and McDonagh (2019), temporal aspects of the evaluation are important.

\subsection{Quality of service associated with the IS}

The role of quality of service has been progressively recognised and proposed through tools such as SERVQUAL. This tool has its origins in marketing (Parasuraman and Zeithmal, 1988) and is an instrument consisting of 44 items to assess the perception of the quality of service by customers in service organisations and retail sales. SERVQUAL was then adapted and validated for use in IS service assessment (Pitt, Watson and Kavan, 1995; Kettinger and Lee, 1997; Watson, Pitt and Kavan, 1998). Note that a SERVQUAL inspired tool called SERVPERF has also been proposed in marketing (Cronin and Taylor, 1992). Myerscough (2002) showed that, in general, the four factors (Reliability, Responsiveness, Assurance, and Empathy) a priori model for SERVQUAL and SERVPERF were poorly fitted to the data. However, Benlian (2013) empirically shows that the increase in user satisfaction with IS quality of service is related to higher levels of perceptual congruence between IT professionals and users. The author indicates that IT-business misalignment can result from a difference in perception between IT professionals and users.

\subsection{Functional evaluation of IS}

Few studies have developed an evaluation of the IS function proposing a validated measurement tool. In their article, Saunders and Jones (1992) identify 11 dimensions of IS function performance and made a three-round Delphi study, conducted among IS executives. They supported these results by interviews with senior executives from corporate management. This approach is based on the observation that managers in different functional areas and levels of the organisation have different perspectives on the performance of the IS function. Chang and King (2005) though, validated a measurement tool, called IS functional scorecard (ISFS), which measures 18 factors on 3 dimensions of the IS: the system performance, the effectiveness of the information and the service performance. The study conducted by Marciniak, Gueugnon and Jouini (2009) on the contribution of the values of the information system to organisational performance, which incorporates elements from the work of Chang and King (2005), proposes a change in performance representation of the IS function as values. This makes it possible to take into consideration the divergent perceptions of the performance of the IS function by the actors of the organisation, according to their role and functional area. In a second study focusing more specifically on the success and effects of the pedagogical intranet, Marciniak, Gueugnon and Elmael (2012) show, through an empirical study of three management schools, that there are significant links between the patrimonial value, the use value and the effects on the users of the intranet site. Their results also show the relevance of this approach. Marciniak, Gueugnon and Elmael (2012) propose a measurement tool specifically adapted to educational intranets. The model derived from this study can be partially compared with the IT infrastructure and personal IT dimensions of the IT capability model (Kim, Bongsik and Kwon, 2013) . Moreover, the study by Albadvi, Keramati and Ramzi (2007) can be likened to functional evaluation. Through a statistical analysis of 200 car part manufacturers, the authors show the influence of IT on the performance of the organisation and mediating role of business processes reengineering. Finally, Guillemette and Paré (2012) proposed a theory of the contribution of the IT function in organisations which provides a point of view of this function and it contribution. However functional evaluation hasn't been studied much compared to the other streams seen previously.

\subsection{Sub-functional evaluation of the IS}

The measurement of sub-functional performance is a highly developed field by IS researchers. Well-known models such as the Technology Acceptance Model -TAM (Davis, 1989; Davis, Bagozzi and Warshaw, 1989) and the Unified Theory of Acceptance and Use of Technology Model (UTAUT) (Venkatesh et al., 2003) are representative of this school of thought. The TAM, based on the theory of reasoned action (Fishbein and Ajzen, 1975) explains the relationship between perceived ease of use, perceived usefulness, attitude toward using, behavioural intention to use, and actual use of IS. Several variants of the model have been proposed including TAM 2 in which, amongst others, the subjective norm variable has been added to account for social influence (Venkatesh and and Davis, 2000) Furthermore, Venkatesh, et al. (2003) proposed a unified model, UTAUT. In the field of intranet analysis, Horton et al. (2001) consider the application of TAM for explaining the use of the intranet in two organisations in the UK. The authors show that perceived usefulness, ease of use and intention of use are factors of acceptance of the intranet. In particular, their study specifies that the perceived ease of use accounts for a significant part of the intranet uptake in the two studied companies. The TAM was also used by 
Norzaidi et al. (2008), who adapted it to measure the impact of user resistance against use of the intranet and its influence on performance of middle managers of a port in Malaysia. In this article, the authors empirically show that: use of the intranet has a strong effect on the performance and that user resistance has little effect on performance. In addition, Barnes and Vidgen (2009) tested a model combining dimensions from both TAM and UTAUT. Their data is collected in the marketing and sales divisions of an international manufacturing company using web-based questionnaires. Their model validates the following four hypotheses (Barnes and Vidgen 2009, p.3-4): "[1] Intranet quality is positively related to behavioural intention to use an intranet, [2] Social influence is positively related to behavioural intention to use an intranet, [3] Perceived usefulness is positively related to behavioural intention to use an intranet, [and 4] Behavioural intention is positively related to actual intranet use". These results are therefore consistent with those of previous studies using the TAM (for the variables concerned). Lee and Kim's (2009) confirmatory study of factors affecting intranet use on the intranet of 10 major Korean companies states that intranet usage is influenced among others by perceived usefulness. This research shows the interest of researchers in understanding sub-functional constituents and their relationship to use, as well as in explaining the acceptance of technologies.

Table 1 summarizes our review of the literature on these various streams of research.

Table 1: Research areas in IS literature and intranets

\begin{tabular}{|l|l|l|}
\hline \multicolumn{1}{|c|}{ Dimension of research } & \multicolumn{1}{|c|}{ General Literature } & \multicolumn{1}{c|}{ Intranet Literature } \\
\hline IS capability & $\begin{array}{l}\text { IT infrastructure investment } \\
\text { (Chatterjee, Pacini and Sambamurthy, } \\
\text { 2002) }\end{array}$ & $\begin{array}{l}\text { (Balasubramanian, Kulatilaka and Storck, } \\
\text { 2000; Andersen, 2001; 2005) }\end{array}$ \\
\hline Effectiveness / Success of IS & $\begin{array}{l}\text { ISSM (DeLone and McLean 1992; 2003) } \\
\text { (Petter, DeLone and McLean, 2008; } \\
\text { 2013) }\end{array}$ & $\begin{array}{l}\text { (Klecun and Cornford, 2003; Mosbey, Baile } \\
\text { and Zeribi, 2012) }\end{array}$ \\
\hline $\begin{array}{l}\text { Quality of service associated } \\
\text { with the IS }\end{array}$ & $\begin{array}{l}\text { SERVQUAL (Parasuraman, Zeithaml and } \\
\text { Berry, 1988; Watson, Pitt and Kavan, } \\
\text { 1998) SERVPERF (Cronin and Taylor, } \\
\text { 1992; Kettinger and Lee, 1997) }\end{array}$ & (Myerscough 2002; Benlian, 2013) \\
\hline Functional IS evaluation & $\begin{array}{l}\text { ISFPEM (Saunders and Jones, 1992), IS } \\
\text { Functional scorecard Chang and King } \\
\text { (2005), } \\
\text { IS values (Marciniak, Gueugnon and } \\
\text { Jouini, 2009) }\end{array}$ & $\begin{array}{l}\text { (Marciniak, Geugnon and Elmael, 2012; } \\
\text { (Albavi, Keramati. and Ramzi, 2007) }\end{array}$ \\
\hline Sub-Functional IS evaluation & $\begin{array}{l}\text { TAM (Davis, 1989), UTAUT (Venkatesh } \\
\text { et al., 2003) }\end{array}$ & $\begin{array}{l}\text { (Norzaidi et al. 2008; Horton et al., 2001) } \\
\text { (Lee and Kim, 2009; Barnes and Vidgen } \\
\text { 2009) }\end{array}$ \\
\hline
\end{tabular}

These areas from the literature base our research in the general streams of evaluation of performance, as well as in streams particularly applied to the intranets. Our model is based on these streams of research but also on the concept of IS values addressed in the functional evaluation that is presented in the next section.

\subsection{The values of the IS function}

Measuring and communicating the value provided by the IS function in the organisation is still a challenge for CIOs. This is explained by the difficulty of showing the existence of a link between the actions performed by the IS function and the financial metrics (financial information) at the organisational level. These metrics have high credibility for executives (Mitra, Sambamurthy and Westerman, 2011).

As a result, information systems are frequently assessed considering only related costs and returns (TCO, ROI, etc.). In order to assess all the value created, intangible values must also be considered. Three categories of values can be distinguished (Marciniak, Gueugnon and Jouini, 2009; Marciniak and Rowe, 2009; Marciniak, Gueugnon and Elmael, 2012).

The first one, the patrimonial value, concerns the quality of the company's IT assets (hardware, software and team know-how) (CIGREF and McKinsey, 2008). The operational excellence of the IS depends on these assets, the value of which is measured using indicators (Marciniak, Gueugnon and Jouini, 2009): response time, mean time between failures, etc. Primary innovation adoption (Gallivan, 2001), is based on consensus at management 
level and supported by approaches aimed at encouraging secondary adoption of the system at the individual level (a form of acceptance).Therefore, in some ways the patrimonial value could be related to the notion of primary adoption.

The second category of value, the use value, concerns the contribution of the information system to the business processes and support processes of the organisation (CIGREF and McKinsey, 2008). It is measured by indicators, specific to each business (Marciniak and Rowe, 2009). Therefore, there is no universal representation of the use value, "it is necessary to analyse the strategic axis of the company and to set business indicators, therefore to set business-information system indicators and finally, set computer indicators" [translated] (Marciniak and Rowe, 2009, p.51). This second value can be compared to the integration of the IS in the use of individuals. Uses embedded in the IS represent organisational routines, "repetitive, recognizable patterns of interdependent actions, carried out by multiple actors" (Feldman and Pentland, 2003, p.95). Considering the organisation, these two kinds of values, patrimonial value and use value are endogenous. Understanding them needs investigation inside the organisation.

Finally, the third category of value, [electronic] exchange value (Marciniak and Rowe, 2009, p.51), is characterized by "the volume and quality of electronic exchanges with various partners (suppliers, customers, etc.) and the nature of the interaction they maintain"[translated]. Exchange value is exogenous vis-à-vis the organisation and external firms.

In our study on the intranets of three schools of management and engineering in France, we focus exclusively on patrimonial and use values.

\section{Hypotheses, model and data collection}

In this section we present the development of the hypotheses and the model (3.1), then the data collection of our study (3.2).

\subsection{Reflective measurement model and hypotheses}

The model presented in Figure 1 is based on the different research streams previously studied; IS capability, efficiency or IS success, IS quality of service, evaluation of the IS function and sub-functional IS evaluation. We focus on the evaluation of the IS function through the IS values because they represent a potential gain in terms of understanding the information system. We now detail the assumptions and present our model.

The success of the intranet is a variable to explain. Models from the work of Delone and Mclean take this important dimension of evaluation into account (Delone and Mclean, 2003; Petter, Delone and McLean, 2013).

The patrimonial value of the information system relates to the IT assets of the organisation (Marciniak and Rowe, 2009). The quality of these assets depends on the "operational excellence" of the IT function (CIGREF and McKinsey, 2008, p.12). Studies by Delone and McLean (2003), which have been widely validated (Petter, Delone and McLean, 2013; Petter, Delone and McLean, 2008), showed the importance of three dimensions of IS; quality of system (1); quality of information (2), mobilised by Klecun and Cornford (2003) in the context of intranets; and quality of service (3) examined in the context of electronic services by Benlian (2013). Thus, the quality of the computer system, the quality of the information as well as the quality of the IS service are three dimensions that reflect different facets of the patrimonial value. The patrimonial value thus constitutes a second-order construct; that is to say, a general construct without specific indicators (Hair et al., 2014). The measurement model is the relation between the first order constructs and their indicators. The measures (reflected by indicators) represent the effect of an underlying construct. These indicators, affected by the same construct, constitute measure scales (Hair et al., 2014). It is why in this research we use reflective measurement models. We now want to check good construction of the reflective measurement model. Concerning the patrimonial value measurement model, we can state:

R1: The perceived patrimonial value of the intranet is reflected in the technical computer system quality subconstruct

R2: The perceived patrimonial value of the intranet is reflected in the information quality sub-construct

R3: The perceived patrimonial value of the intranet is reflected in the service quality sub-construct associated with the intranet 
The use value represents the contribution of the intranet to user effectiveness and is measured on the basis of business indicators. It cements the integration of the system by users, and the "routinization" of uses. The routines have been addressed in several works (Kim, Bongsik and Kwon, 2013; Feldman and Pentland, 2003). In our context of the pedagogical intranet, learning and collaboration are two relevant dimensions because they testify to the support provided by the system to the pedagogical purpose in its multiple individual and social forms. Work in the field has already focused on several dimensions (Marciniak, Geugnon and Elmael, 2012). So the use value is reflected in two sub-constructs: learning and collaboration. We thus constitute the two following measurements:

R4: The perceived use value of the intranet is reflected in the learning sub-construct R5: The perceived use value of the intranet is reflected in the collaboration sub-construct

After building up our second-order variables: patrimonial value and use value, we can make our hypotheses about their causal relationships.

Patrimonial value is the basic structure on which uses can be built in a form of routinization. The patrimonial value is therefore a necessary condition for both the use and the success of the intranet site. In evaluation, the models from Delone and Mclean take into account this success dimension of the IS (Delone and McLean 1992; Delone and McLean, 2003; Petter, Delone and McLean, 2008; Petter, Delone and McLean, 2013). So we can state the following hypothesis:

Hypothesis H1: The patrimonial value positively influences the success of the intranet

In the organisation the information system is a support for user's work which links several dimensions (Chang and King, 2005). Patrimonial value is conceived here as a support for the use value because the patrimonial structure precedes the use that represents the potential integration of the system by its users. That seems to be related to some aspects studied by Gallivan, (2001). Any failure in patrimonial value should encumber the use. On the other hand, positive patrimonial value should improve use; the patrimonial value therefore has a positive influence on use value and organisational impact ), hence the following hypotheses:

Hypothesis H2: The patrimonial value has a positive organisational impact

Hypothesis H3: The patrimonial value positively influences the use value

Finally, the patrimonial value must be developed so that the use value can be expressed (CIGREF-McKinsey, 2008). If the patrimonial value is a necessary support for the use value, it is the latter which precipitates useful value for the business. The use value therefore influences success of the IS, but also produces an organisational impact. The organisational impact could be influenced by the cross-effects of quality of the system, information and service through use (intention) and satisfaction (Petter, Delone and McLean, 2008; Santhanam and Hartono, 2003). So it appears to be relative to the use value. Therefore, the use value relies on technological capabilities and organisational performance.That's why we make the following assumptions:

Hypothesis H4: The use value positively influences the success of the intranet

Hypothesis H5: The use value has a positive organisational impact

Our research model, based on the hypotheses formulated above, mobilizes several sub-constructs and constructs as shown in Figure 1 (detail in appendix 1). The choice between reflective or formative construct was made considering the conditions set out by Jarvis, MacKenzie and Podsakoff (2003). A construct is considered reflective if all its items are caused by the same construct. Items associated with a particular construct must be highly correlated (Hair et al., 2014). This can be verified in our analysis using the KMO test and the Bartlett sphericity test. The internal validity of the scale is measured by Cronbach's alpha. The set of validity measures is detailed in Section 5 of the article. 


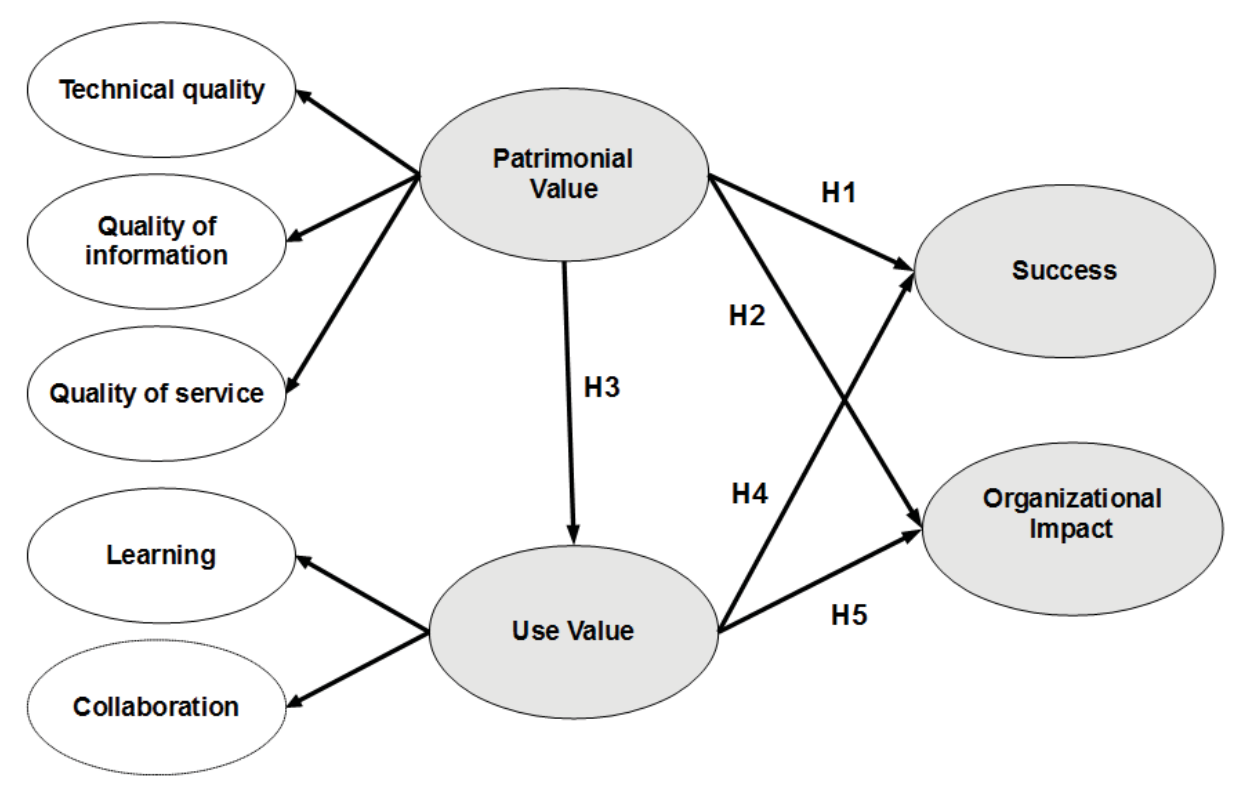

Figure 1: Initial research model

\subsection{Data collection}

Our research field is made up of three French schools of management and engineering. Higher education institutions have been developing intranets for several years. As we want to understand stable IS values, we need to choose organisations that have not recently deployed their intranets to avoid recent implementation side effects. The three schools chosen satisfy this constraint and so are appropriate for our study. The first one is a management school of a university in the Auvergne Rhône-Alpes region ( $A$ ), the second is an engineering school in the Auvergne Rhône-Alpes region (B) and the third one is a management school of a university in the Occitanie region (C).

The respondents are students of these schools because students are the final beneficiaries of the intranet. The aim of the intranet is to carry information to the learners and communicate with them (download files, upload work, consult information, etc.). They were invited by email to answer an online questionnaire. In the sample for the first school (A) we kept 107 valid questionnaires (out of 152), in the second school (B) 349 (out of 483) and in the third school (C) 101 (out of 133). Descriptive statistics of the samples are provided in Appendix 2. Data were collected between 21/02/2014 and 18/03/2014 (school A), between 26/04/2016 and 30/06/2016 (school B) and 25/09/2016 and the $01 / 12 / 2016$ (school C). We chose to focus on the students because they are the end customers of the learning intranet and they form a sufficient sample to use structural equation modelling. Other groups like administrative staff or teachers have others interests about the intranet, and so they should be analysed separately.

In our questionnaire we opted for Likert scales mainly from "not at all" 1 to "yes absolutely" 4, plus a "don't know" modality. We included the "don't know" modality to counteract acquiescence and unconvinced responses (O'Muircheartaigh, Krosnick and Helic, 2001; Kristensen and Eskildsen, 2010).

The "don't know" responses are estimated by the NIPALS algorithm (Wold, 1973). An item on the availability of the intranet, "the intranet is always / never accessible" (with Likert gradations for satisfaction), was included in the questionnaire to assess quality of the infrastructure. This showed that the infrastructure worked well in all three schools.

Analysis of descriptive statistics (presented in Appendix 2) shows that the number of don't know responses can be divided into three categories. The first is for the majority of the items which were easy to answer. The second category shows an increase in the difficulty of answering items, requiring a particular reflection on the richness of the functionalities. The third category indicates an inability to respond to quality of service items only. This is explained by the fact that many students had never contacted the technical service. Moreover, faced with this large number of don't know responses for the service quality sub-construct, we removed it from our model (requires further research) (see Figure 2). 


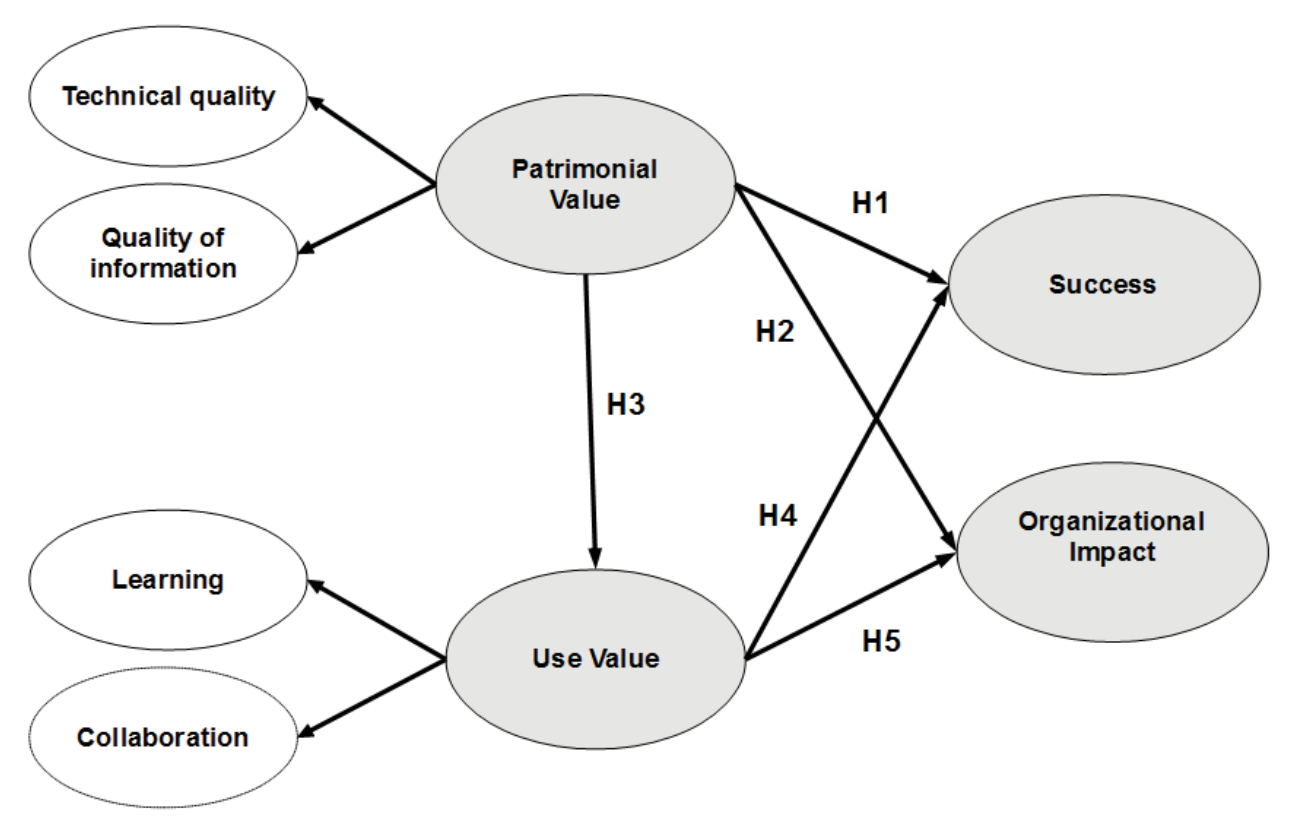

Figure 2: Modified research model

\section{PLS data processing}

In previous sections we described our structural modelling and how information from questionnaire respondents allows quantitative data processing. Here we detail our choice of partial least squares structural equation modelling (PLS-SEM).

The construction of latent models estimated by PLS has been named soft modelling by Herman Wold due to the lack of special conditions for data distribution (Lohmöller, 1989, p.28; 64). After exploratory analysis with PLS (Cohard, 2015), and for reasons of overall coherence the method chosen is PLS-SEM. The small sample sizes for schools A and C are also compatible with this method of treatment (Ringle, Sarstedt and Straub, 2012). We also use bootstrapping in our processing (samples generated by random draws from the initial data). Analysis of the sample size is worked and presented in section 5.

Guidelines for the presentation of PLS results were proposed by (Marcoulides and Saunders, 2006; Reinartz, Haenlein and Henseler, 2009; Gefen, Rigdon and Straud, 2011; Hair, Ringle and Sarstedt, 2011). These guidelines indicate required elements when dealing with the measurement model as with the structural model. Model indicators can be reflective or formative and make it possible to judge the validity of measurements and constructs. Guidelines in the literature advocate testing the statistical power of sample sizes being processed, confirming the validity of measurement scales and also suggest limit values. Section 5 describes our implementation of these guidelines in our research and derived outcomes.

\section{Implementation of the research}

First, we determine the statistical power related to the sample size $(5.1)$ based on the Cohen tables $(1988,1977)$ using Gpower 3 software (Faul et al., 2009). Then we integrate the data into the XLSTAT software in order to perform statistical processing using the partial least squares (PLS) algorithm with path modelling (5.2).

\subsection{Sample size and statistical power}

The power of a statistical test is the probability (1- $\beta$ ) of rejecting the null hypothesis while it is false (thus not to suffer type 2 error). Cohen (1977, p.56) proposes as a convention to set the value of the power of the test 1- $\beta$ to 0.80 , so we set the error threshold of type 1 to $5 \%$, that of type 2 to $20 \%$. This is necessary in our treatment to determine the risk of not detecting a small effect. For this we calculate the size of the effect $\mathrm{f}^{2}$, then the value of $R^{2}$ critical. We perform the sample size calculations using the adapted method (Chin and Newsted, 1999; Chin, 2010), using GPower 3 software (Faul et al., 2009). The results are shown in Table 2. 
Table 2: Sample size and statistical power

\begin{tabular}{|l|c|c|c|l|}
\hline \multicolumn{1}{|c|}{ Criterion } & School A & School B & \multicolumn{1}{c|}{ School C } & \multicolumn{1}{c|}{ Values } \\
\hline Level of signification $\alpha$ & \multicolumn{3}{|c|}{0.05} & $\alpha=5 \%$ \\
\hline Statistical power, 1- $\beta$ & \multicolumn{3}{|c|}{0.80} & Cohen 1977, 1988 \\
\hline Sample size & $\mathrm{n}=107$ & $\mathrm{n}=348$ & $\mathrm{n}=101$ & Sample size \\
\hline Effect size & $f^{2}=\mathbf{0 . 0 9 2 7}$ & $f^{2}=\mathbf{0 . 0 2 7 6}$ & $f^{2}=\mathbf{0 . 0 9 8 4}$ & $\begin{array}{l}\text { 0,02 Small, 0,15 Medium, 0,35 } \\
\text { Large }\end{array}$ \\
\hline $\mathrm{R}^{2}$ min & $R^{2}=\mathbf{0 . 0 8 5}$ & $R^{2}=\mathbf{0 . 0 2 7}$ & $R^{2}=\mathbf{0 . 0 9 0}$ & $\mathrm{f}^{2}=\mathrm{R}^{2} /\left(1-\mathrm{R}^{2}\right)$ and $\mathrm{R}^{2}=\mathrm{f}^{2} /\left(1+\mathrm{f}^{2}\right)$ \\
\hline
\end{tabular}

Thus, according to our samples we can detect weak effects (from $f^{2}=0.0276$ to $f^{2}=0.0984$ ) to a threshold $\alpha$ of $5 \%$ and a statistical power $1-\beta$ of $80 \%$, enabling if necessary to reject with certainty the null hypothesis up to limit values of $R^{2}=0.085$ for sample $A$ and $R^{2}=0.027$ for sample $B$ and $R^{2}=0.090$ for sample $C$.

\subsection{Validity of the constructs}

Our study of construct validity is based on the PLS guidelines previously mentioned. In a preliminary study we reduced the number of items by a principal component analysis (Cohard, 2015). In this research, our analysis of the measurement model for reflective constructs takes into account: the internal validity of the scale by Cronbach's alpha; the composite reliability; the convergent validity by the average variance extracted (AVE) and the discriminant validity by the criterion of Fornell and Larker.

Cronbach's alpha as well as the composite reliability shows the validity of the measurement scales. The AVE always higher than 0.5 reveals that the standardized indicators of the constructs share more variance on average with their construct than with their measurement error. So the convergent validity is reached. Finally, for the criterion of Fornell and Larker, the square root of the AVE must be greater than the $\mathrm{R}^{2}$ between the other latent constructs, is validated on all these constructs which indicates that the discriminant validity is also obtained. The overall measurement model evaluation indicator for the three schools is detailed in Table 3.

Table 3: Extracts from evaluation of the measurement model

\begin{tabular}{|c|c|c|c|c|c|c|}
\hline \multirow{2}{*}{$\begin{array}{l}\text { Measurement model, } \\
\text { Reflective constructs }\end{array}$} & \multicolumn{2}{|c|}{ Sample A } & \multicolumn{2}{|c|}{ Sample B } & \multicolumn{2}{|c|}{ Sample C } \\
\hline & $\begin{array}{l}\text { Cronbach's } \\
\text { alpha }\end{array}$ & AVE & $\begin{array}{l}\text { Cronbach's } \\
\text { alpha }\end{array}$ & AVE & $\begin{array}{l}\text { Cronbach's } \\
\text { alpha }\end{array}$ & AVE \\
\hline Technical quality (5 items) & 0.757 & 0.510 & $\begin{array}{r}0.626 \text { to } \\
0.775 \\
\end{array}$ & 0.858 & 0.640 & $\begin{array}{r}0.729 \text { to } \\
0.861 \\
\end{array}$ \\
\hline $\begin{array}{l}\text { Quality of information (5 } \\
\text { items) }\end{array}$ & 0.768 & 0.524 & $\begin{array}{r}0.623 \text { to } \\
0.853 \\
\end{array}$ & 0.900 & 0.714 & $\begin{array}{r}0.881 \text { to } \\
0.797 \\
\end{array}$ \\
\hline Collaboration & 0.856 & 0.639 & $\begin{array}{r}0.650 \text { to } \\
0.946 \\
\end{array}$ & 0.893 & 0.705 & $\begin{array}{r}0.721 \text { to } \\
0.897 \\
\end{array}$ \\
\hline Learning & 0.868 & 0.795 & $\begin{array}{r}0.800 \text { to } \\
0.938\end{array}$ & 0.837 & 0.758 & $\begin{array}{r}0.920 \text { to } \\
0.776 \\
\end{array}$ \\
\hline $\begin{array}{lll}\begin{array}{l}\text { Organisational Impact } \\
\text { items) }\end{array} & & \\
\end{array}$ & 0.876 & 0.730 & $\begin{array}{r}0.799 \text { to } \\
0.899 \\
\end{array}$ & 0.951 & 0.871 & $\begin{array}{r}0.926 \text { to } \\
0.944 \\
\end{array}$ \\
\hline Success & $\mathrm{NC}$ - unique ite & & & & & \\
\hline
\end{tabular}

We carry out a study of collinearity of the structural construct. Since all the values are below the critical threshold $(\mathrm{VIF}<5)$, we can conclude that there is no collinearity problem in our analysis.

\section{Results}

We now present the results of partial least squares analysis of our structural model. They are presented by $\mathrm{T}$ test significance of path linkages via bootstrapping (resample $=5000$ ) and analysis of $R^{2}$ values as well as the $Q^{2}$ values of Stone and Geisser which is the index of redundancy in cross validation. 
It appears that all the paths are significant because the T value is greater than the limit value (T> 1.96), with the exception of the patrimonial value link $\rightarrow$ organisational impact for sample A only, the value of which is 0.886 . We note that the patrimonial value, second order construct, has strong links with the quality of the information (0.859 A, 0.891 B, 0.862 C) but also with the technical quality (0.877 A, 0.878 B, 0.768 C) (see Table 4). The patrimonial value is also strongly linked to the success of the intranet $(0.354 \mathrm{~A}, 0.525 \mathrm{~B}, 0.611 \mathrm{C})$ and the organisational impact $(0.315 \mathrm{~B}, 0.427 \mathrm{C})$. Similarly, the use value is linked both to the success of the intranet (0.357 A, $0.315 \mathrm{~B}, 0.218 \mathrm{C}$ ) and the organisational impact (0.627 A, $0.457 \mathrm{~B}, 0.408 \mathrm{C}$ ) (see Table 6).

Table 4: Tests of the measurement model

\begin{tabular}{|c|c|c|c|c|c|c|c|c|}
\hline \multirow{2}{*}{\multicolumn{2}{|c|}{ Reflective measurement model }} & \multirow{3}{*}{$\begin{array}{l}\text { Decision } \\
\text { Validity }\end{array}$} & \multicolumn{2}{|r|}{ A } & \multicolumn{2}{|c|}{ B } & \multicolumn{2}{|r|}{ C } \\
\hline & & & \multirow{2}{*}{$\begin{array}{l}\text { T Test } \\
43.829\end{array}$} & \multirow{2}{*}{$\begin{array}{r}\begin{array}{c}\text { Path } \\
\text { coefficient }\end{array} \\
0.877\end{array}$} & \multirow{2}{*}{$\begin{array}{l}\text { T Test } \\
34.146\end{array}$} & \multirow{2}{*}{$\begin{array}{r}\begin{array}{c}\text { Path } \\
\text { coefficient }\end{array} \\
0.878\end{array}$} & \multirow{2}{*}{$\begin{array}{l}\text { T Test } \\
11.930\end{array}$} & \multirow{2}{*}{$\begin{array}{r}\begin{array}{c}\text { Path } \\
\text { coefficient }\end{array} \\
0.768\end{array}$} \\
\hline $\mathrm{R} 1$ & $\begin{array}{l}\text { Patrimonial value } \rightarrow \\
\text { Technical quality }\end{array}$ & & & & & & & \\
\hline $\mathrm{R} 2$ & $\begin{array}{l}\text { Patrimonial value } \rightarrow \\
\text { Information quality }\end{array}$ & Validity & 23.812 & 0.859 & 36.571 & 0.891 & 16.942 & 0.862 \\
\hline$R 3$ & $\begin{array}{l}\text { Not tested } \\
\text { (quality of service) }\end{array}$ & Not tested & -- & -- & -- & -- & -- & -- \\
\hline R4 & $\begin{array}{l}\text { Use value } \rightarrow \\
\text { Learning }\end{array}$ & Validity & 29.413 & 0.835 & 33.122 & 0.872 & 18.560 & 0.881 \\
\hline R5 & $\begin{array}{l}\text { Use value } \rightarrow \\
\text { Collaboration }\end{array}$ & Validity & 40.408 & 0.895 & 49.793 & 0.937 & 30.182 & 0.950 \\
\hline
\end{tabular}

Table 5 shows that the values of $\mathrm{Q}^{2}$ are positive indicating a predictive validity, with the exception of the use value in the sample $C$ which can be explained as edge effect of the reduced sample size. Patrimonial value represents the effect of the underlying constructs Information quality and technical quality; it is a second-order construct by repetition of the indicators (Chin, 2010). Similarly, use value represents the effect of underlying constructs collaboration and learning which is also a second-order construct. The success of the intranet is explained at $36 \%$ (A); $58 \%$ (B) and $54 \%$ (C) by both patrimonial value (PV) and use value (UV), which corroborates the nature of the links between these constructs and the success of the intranet respectively $(\mathrm{Ppv}=0.354, \mathrm{Tpv}$ $=3.497$, Puv $=0.357$, Tuv $=4.452$ ) in sample A, for example. It is interesting here to note the direct effect of use value and patrimonial value on the success of the intranet, the indirect effect of patrimonial value on the success of the intranet by use value as mediator. This indirect effect can be calculated as the product of both effects (Hair et al. 2014): Ppv-uv x Puv-successIS, respectively: 0.162 for school A; 0.199 for school B and 0.104 for school C. This means the indirect effect reinforces the influence of patrimonial value on the success of the intranet. Organisational impact is explained at $44 \%$ (school A), 49\% (school B) and 51\% (school C) by the patrimonial value (PV) and the use value (UV); this confirms the nature of the links between organisational impact and these constructs. Although the link between the patrimonial value (PV) and the organisational impact is not significant with sample $A(T p v=0.886)$, it is significant in the two other samples $(T=6.3$ and $T=5.3$ respectively for cases $B$ and $C$ ). We can calculate the indirect effect of patrimonial value on organisational impact by use value as mediator: Ppv-vu x Puv -impact.org. respectively 0.285 in the case of school A; 0, 289 for school B; and 0.194 in case $C$. Note that the use value is explained at $21 \%$ by the patrimonial value which also corroborates the links between these variables $(P=0.455, T=5.295)$; the use value is also a second-order construct. The negative value of $Q^{2}$ for this construct in case $C$ indicates that no predictive relevance was found for this construct for this case. Finally, the patrimonial value is empty because it does not have a predictive variable to calculate the $\mathrm{R}^{2}$. 
Table 5: $R^{2}$ et $Q^{2}$ coefficients

\begin{tabular}{|c|c|c|c|c|c|c|}
\hline \multirow[b]{2}{*}{ Endogenous latent Variables } & \multicolumn{2}{|c|}{ A } & \multicolumn{2}{|c|}{ B } & \multicolumn{2}{|c|}{ C } \\
\hline & $\mathbf{R}^{2}$ & $Q^{2}$ & $\mathbf{R}^{2}$ & $Q^{2}$ & $\mathbf{R}^{\mathbf{2}}$ & $Q^{2}$ \\
\hline Information quality & 0.738 & 0.379 & 0.794 & 0.571 & 0.744 & 0.490 \\
\hline Technical sys quality & 0.769 & 0.387 & 0.771 & 0.363 & 0.590 & 0.114 \\
\hline Learning & 0.698 & 0.548 & 0.760 & 0.425 & 0.777 & 0.438 \\
\hline Collaboration & 0.801 & 0.504 & 0.878 & 0.626 & 0.902 & 0.577 \\
\hline Organisational impact & 0.449 & 0.301 & 0.490 & 0.358 & 0.514 & 0.343 \\
\hline Success of the intranet & 0.367 & 0.357 & 0.585 & 0.542 & 0.548 & 0.460 \\
\hline USE VALUE* & 0.207 & 0.104 & 0.400 & 0.132 & 0.226 & -0.074 \\
\hline PATRIMONIAL VALUE* & -- & -- & -- & -- & -- & -- \\
\hline
\end{tabular}

Based on our analyses, five tested hypotheses linking latent variables are found to be significantly positive at the $0.01 \%$ level as shown in Table 6 below. One hypothesis could not be tested because of numerous don't know answers. One tested hypothesis is partially accepted because the effect exists but is validated on only two samples (B and C).

Table 6: Validated hypotheses

\begin{tabular}{|c|c|c|c|c|c|c|c|c|}
\hline & & & & A & & B & & C \\
\hline Hyp & theses & Decicion & T Tout & Path & T Tot & Path & T Tot & Path \\
\hline $\mathrm{H} 1$ & $\begin{array}{l}\text { Patrimonial value } \rightarrow \\
\text { Success of the Intranet }\end{array}$ & Accepted & 3.497 & 0.354 & 11.725 & 0.525 & 7.918 & 0.611 \\
\hline $\mathrm{H} 2$ & $\begin{array}{l}\text { Patrimonial value } \rightarrow \\
\text { Organisational impact } \\
\end{array}$ & Accepted * & 0.886 & 0.086 & 6.354 & 0.315 & 5.334 & 0.427 \\
\hline H3 & $\begin{array}{l}\text { Patrimonial value } \rightarrow \\
\text { Use value }\end{array}$ & Accepted & 5.295 & 0.455 & 15.187 & 0.632 & 5.370 & 0.475 \\
\hline $\mathrm{H} 4$ & $\begin{array}{l}\text { Use value } \rightarrow \\
\text { Success of the Intranet }\end{array}$ & Accepted & 4.452 & 0.357 & 7.039 & 0.315 & 2.827 & 0.218 \\
\hline $\mathrm{H} 5$ & $\begin{array}{l}\text { Use value } \rightarrow \\
\text { Organisational impact }\end{array}$ & Accepted & 7.578 & 0.627 & 9.2016 & 0.457 & 5.098 & 0.408 \\
\hline
\end{tabular}

Finally, we calculated the Goodness of Fit index proposed by Tenenhaus, Amato and Esposito Vinzi (2004), $\mathrm{GoF}=0.51$ for school $\mathrm{A}, \mathrm{GoF}=0.66$ for school $\mathrm{B}$ and $\mathrm{GoF}=0.60$ for School C reflecting good overall model quality (GoF>0.36), although this GoF is controversial.

Despite our efforts, certain limits persist as indicated below, the exceeding of which could be the subject of extensions in future research. In particular, the sub-construct quality of service related to patrimonial value could not be validated because effects that were not present in the mobilized literature have been found. Thus quality of service as technical support needs to be measured in a different way, because users either have ad hoc resort to technical support making their evaluation random, or they have never had contact with technical support, making their evaluation impossible. These findings may lead to new questions: Is service a necessary indicator for intranet success? Is the intranet strongly linked to the quality of service? Has quality reached a high enough level to obviate a requirement for assistance on this system? These questions would interest other categories of users including teachers and administrative staff in new research on quality of service linkage with IS success. Confirmation with other types of organisations (and other types of information systems) would be required, adapting the use value items. 
In addition, although our study is based on three samples, we believe that it should be validated in other management schools and with other types of stakeholders such as teachers. This is also an extension of our research.

The main results of our research (RR) are:

RR1 - Patrimonial value influences success of the intranet $(P A=0.354, T A=3.497, P B=0.525, T B=11.725, P C=$ $0.611, \mathrm{TC}=7.918$ ).

RR2 - Patrimonial value influences organisational impact (validated on two samples $P B=0.315, T B=6.354, P C=$ $0.427, \mathrm{TC}=5.334$ )

RR3 - Use value influences success of the intranet $(P A=0.357, T A=4.452, P B=0.315, T B=7.039, P C=0.218, T C$ $=2.827)$.

RR4 - Use value influences organisational impact $(P A=0.627, T A=7.578, P B=0.457, T B=9.206, P C=0.408, T C$ $=5.098$.

RR5 - Patrimonial value significantly and positively influences use value $(P A=0.455, T A=5.295, P B=0.632, T B$ $=15.187, \mathrm{PC}=0.475, \mathrm{TC}=5.370)$.

RR6 - Use value is a mediator of patrimonial value both on success of the intranet (0.162 A, $0.199 \mathrm{~B}$ and 0.104 C) and organisational impact (0.285 A, 0.289 B and 0.194 C).

The validated research model with accepted hypotheses is presented below in Figure 3.

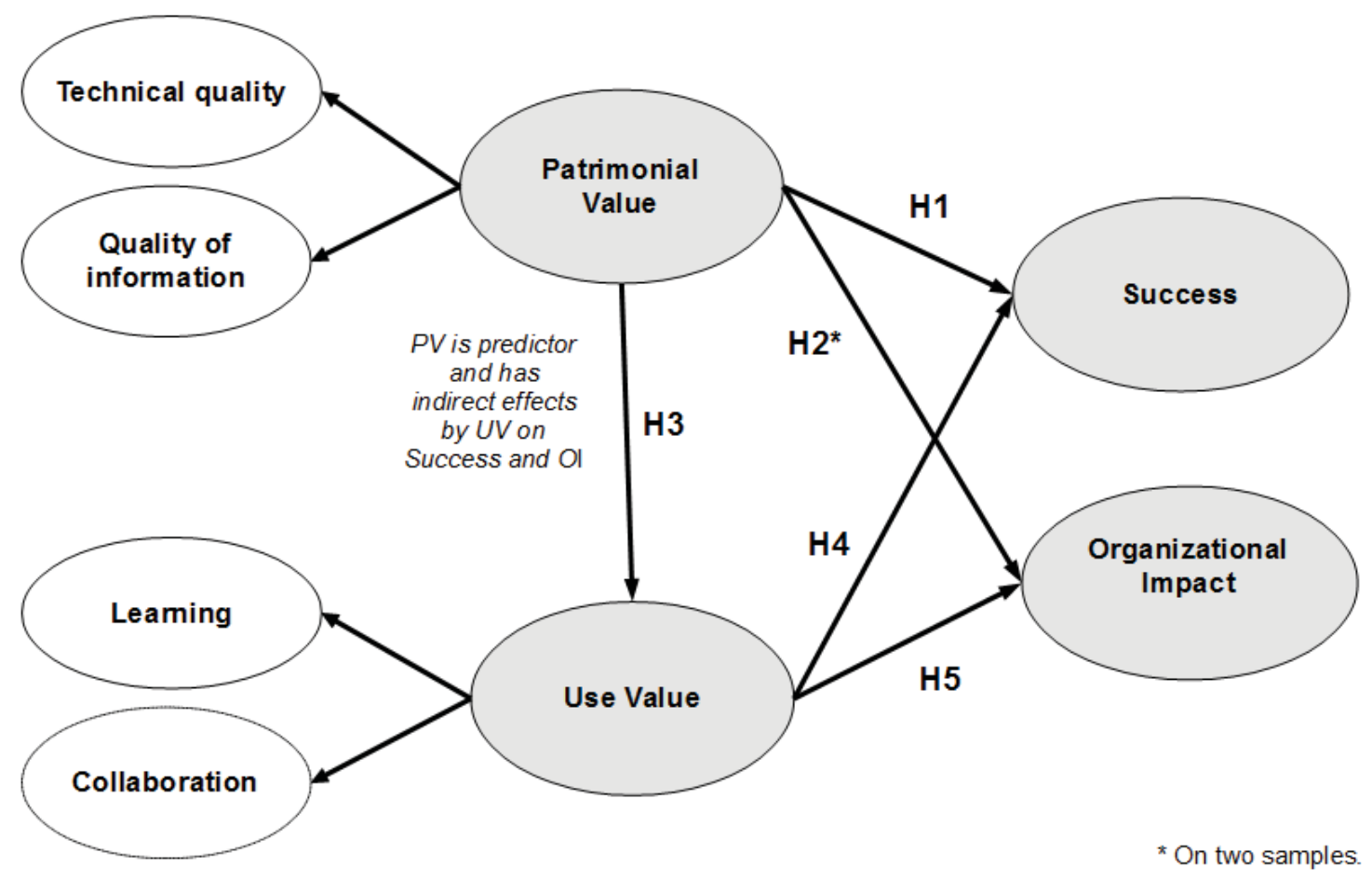

Figure 3: Revised model

\section{Discussion}

From our review of the literature we have made assumptions and founded our research model. Then in a second step, thanks to our model, we have built a questionnaire that we used in the context of data collection in three schools of management and engineering in France. Then we proceeded to analysis of the data by the PLS-SEM. The design of the model, its analysis and its validation make it possible to answer our research question which was: How do patrimonial and use values influence the success and organisational impact of an intranet? By providing a measurement tool we have indicated how to measure the patrimonial value and use value of the intranet. By showing a number of relationships between constructs, our research responds to this question. It 
provides a better understanding of the phenomena that link intranet values, intranet success, and organisational impact.

In this article we have analysed relationships between patrimonial value and use value. Patrimonial value significantly influences use value, so it appears to be fundamental. We have shown in our study that patrimonial value not only contributes to use value, but also contributes directly to organisational impact and success of the IS. Our study tends to show that there is a complex relationship between patrimonial value, use value, organisational contribution and success. Some dimensions are mediated by use value, others contribute to use value, and some are directly related to patrimonial value. This makes us wonder whether use value has a major impact and contribution to organisational success. The strong and direct influence of patrimonial value on success and organisational impact shows also that use value is not the only one to participate in these relations, but that it has a second level of effect that mediates, in part, the patrimonial value. Use value is a mediator of patrimonial value, but it also has a direct influence on organisational impact and success. This is to say that, beyond transforming the patrimonial value into use, it allows the creation of a certain added value related to the accomplishment of tasks. This value is related to the coordination and facilitation of work.

We presented a questionnaire aimed at revealing patrimonial and use values of the IS (,. The relationship between patrimonial value and use value seems to be related to adoption (Gallivan, 2001) and integration of the IS into the organisation (routines) (Feldman and Pentland, 2003). The result - patrimonial value significantly and positively influences use value - RR5 which reveals that beyond the provision of technologies, there is a form of routinisation of the use of the intranet; the use value is only materialized in the very use of the system. Our research shows that the patrimonial value has a strong influence on the use value. The proposed model thus makes it possible to explain and document the relationship between patrimonial value and use value. Based on these results and explanations, the evaluator can make a detailed description stating strengths and weaknesses of the intranet. As specified by Guba and Lincoln (1989), description is taken into consideration in the thirdgeneration evaluation (judgment) that makes it possible to judge how the intranet is adjusted to the user's own use (based on measures and descriptions). A weak link between these two constructs would show the availability of a technically efficient intranet but without real value in terms of use. However, if the link is significant enough it may confirm that there is a fit between technology and the task.

Patrimonial value with its two sub-constructs, technical system quality and quality of information, holds a central role in our analysis, which is corroborated by the study of Marciniak, Geugnon, and Elmael (2012) and is consistent with models used by Petter, Delone and McLean (2008), and Delone and Mclean (2003). The influence of patrimonial value and use value on the success of the intranet (RR1-RR3) is significant, which seems also consistent with the Petter, Delone and McLean (2008) model and the intranet evaluation proposed by Klecun and Cornford (2003). Our study indicates that the patrimonial value influences both the success of the intranet and the organisational contribution (RR1-RR2). These results are also congruent with those of Marciniak, Geugnon and Elmael (2012) for the influence of use value on success (RR3).

These results show that managers in their design effort, reflected in the patrimonial value and materialised in the use value, have overcome any implicit assumptions to choose good design alternatives as suggested by the sociotechnical approach of Bostrom and Heinen (1977). Our research can establish that use value also mediates the patrimonial value of organisational success and impact (RR6). Moreover, our study shows that the influence of the use value on the organisational impact is strong (RR4). The cross-referencing of these results shows the validity both internally, through our statistical analyses, and externally through other studies.

We think that these results can be extended to other populations of the same nature (schools, training institutes, etc.). A transfer of this research to other types of structures should be undertaken. This would further expand the external validity of this research in other areas.

Our results bring the following theoretical contributions. In our research, we have shown the relationship between patrimonial value and use value, as well as organisational success and impact. We have shown that patrimonial value influences use value, success and organisational impact and that use value influences success and organisational impact.

We have also shown that the use value plays a role in mediating the patrimonial value over organisational success and impact to a certain extent. Patrimonial value and use value are independent variables, while success 
and organisational impact are dependent variables. The patrimonial value is also a variable independent of the use, the latter testifying to the fit with the task that results from a suitable design of the intranet. Thus, the suggested model can be assimilated to the third generation of evaluation of Guba and Lincoln (1989), the judgment.

The measures and descriptive evaluation, via the model, make it possible to develop an assessment on the adequacy of the intranet.

Moreover, this research brings managerial contributions. Through the use of the questionnaire, enterprises can evaluate their intranet and identify potential dimensions for improvement which allow before-and-after comparisons based on patrimonial value and use value.

\section{Conclusion}

Evaluation of IS performance cannot rely only on typical accounting metrics because the value is also based on intangible effects they have on an organisation and is thus difficult to measure. Based on our review of the IS evaluation literature, we identified a research gap and developed a theoretical framework to understand patrimonial value (i.e., quality of the hardware, software and IT services) as well as use value (realized in IS use). Our research question is: How do patrimonial and use values influence success and organisational impact of an intranet? We made hypotheses, established our research model, collected data via questionnaires and analysed the data using the PLS-SEM (partial least squares) method.

These findings bring theoretical contributions showing the relationship between patrimonial value and use value. Our conclusion is that the design of the model, its validation and analysis of the data does make it possible and practicable to understand relationships between patrimonial and use values. We have shown that both values influence success and organisational impact but it is important to understand the subtleties of the relationships between those values. In this, the use value appears to play a role in mediating the patrimonial value while patrimonial value is a fundamental enabling factor for the use value. These findings allow a change in approach to evaluating performance of IS by questionnaire while simultaneously identifying IS limitations.

Moreover, this research brings practical contributions in providing a tool and framework to measure and understand the impact on an organisation of those values and their relationships thereby offering a means to improve an intranet. Indeed, IS performance evaluation has an important role to play in decision support. After an intranet has been examined in terms of values, our framework can indicate those dimensions where improvements should be considered a priority for optimising the impact on an organisation. These findings make a contribution to the body of knowledge in the evaluation of information systems. Finally, we suggest extensions for future research such as testing the model with different profiles, in other kinds of organisations and introducing new dimensions and variables.

\section{References}

Albadvi, A., Keramati, A. and Ramzi, J., 2007. Assessing the impact of information technology on firm performance considering the role of intervening variables: organisational infrastructures and business processes reengineering. International Journal of Production Research, 45(12), pp.2697-2734.

Andersen, T. J. 2001., Information technology, strategic decision making approaches and organisational performance in different industrial settings. Strategic Information Systems, 10(2), pp. 101-119.

Andersen, T. J. 2005., The performance effect of computer-mediated communication and decentralized strategic decision making. Journal of Business Research, 58(8), pp. 1059-1067.

Balasubramanian, P., Kulatilaka, N. and Storck, J., 2000. Managing information technology investments using a real-options approach. The Journal of Strategic Information Systems, 9(1), pp. 39-62.

Barnes, S. and Vidgen, R. 2009., An evaluation of user acceptance of a corporate intranet. In: 17th European Conference on Information Systems, ECIS 2009, 2009, Italy: Verona.

Benlian, A., 2013. Effect mechanisms of perceptual congruence between Information Systems professionals and users on satisfaction with service. Journal of Management Information Systems, 29(4), pp. 63-96.

Bostrom, R. and Heinen, S., 1977. MIS problems and failures: a socio-technical perspective. MIS Quarterly, 1(3), pp.17-32.

Bounfour, A. and Epinette, G. 2006. Valeur et performance des SI: une nouvelle approche du capital immatériel de l'entreprise. Paris: Dunod.

Chang, J. and King, W. 2005., Measuring the performance of Information Systems: a functional scorecard. Journal of Management Information Systems, 22(1), pp. 85-115. 
Chatterjee, D., Pacini, C. and Sambamurthy, V., 2002. The shareholder-wealth and trading-volume effects of informationtechnology infrastructure investments. Journal of Management Information Systems, 19(2), pp. 7-42.

Chin, W. 2010., How to write up and report PLS analyses. In: V. E. Vinzi, J. Henseler, and H. Wang. eds.2010. Handbook of Partial Least Squares Concepts, Methods and Applications. Heidelberg: Springer-Verlag. pp. 665-690.

Chin, W. and Newsted, P., 1999. Structural equation modeling analysis with small samples using partial least squares. In: R.H. Hoyle. 1999. Statistical strategies for small sample research. Thousand Oaks; Sage Publications, pp. 307-341.

CIGREF-McKinsey, 2008. Dynamique de création de valeur par les Systèmes d'Information. France: CIGEF-McKinsey.

Cohard, P., 2015. De la performance perçue des systèmes d'information aux valeurs fonctionnelles du SI: le cas de l'intranet d'une école de management de la région Rhône-Alpes, AIM'2015, Rabat, pp. 1-36.

Cohen, J., 1977. Statistical power analysis for the behavioral sciences. New York: Academic Press.

Cohen, J., 1988. Statistical Power Analysis for the Behavioral Sciences. New Jersey: Lawrence Erlbaum Associates.

Cronin, J. and Taylor, S., 1992. Measuring service quality; a reexamination and extension. Journal of Marketing, (56), pp. 55-68.

Davis. F., 1989. Perceived usefulness, perceived ease of use, and user acceptance of information technology. MIS Quarterly, 13(3), pp. 319-339.

Davis, F., Bagozzi, P. and Warshaw, P., 1989. User acceptance of computer technology: a comparison of two theoretical models. Management Science, 35(8), pp. 982-1003.

Delone, W. and McLean, E., 1992. Information Systems success: the quest for the dependent variable. Information Systems Research, 3(1), pp. 60-95.

Delone, W. and McLean, E., 2003. The DeLone and McLean model of Information Systems success: a ten-year update. Journal of Management Information Systems, 19(4), pp. 9-30.

Elmael, M., 2011. Utilisation de l'intranet pédagogique dans les trois écoles. Clermont-Ferrand, Strasbourg, Tripoli. PhD., Université Paris Ouest, France.

Erickson, S., and Rothberg, H. 2019. Toward a deeper understanding of competitive knowledge assets. The Electronic Journal of Knowledge Management, 17(1), pp. 79-88.

Faul, F., Erdfelder, E., Buchner, A. and Lang, A.G., 2009. Statistical power analyses using G*Power 3.1: Tests for correlation and regression analyses. Behavior Research Methods,41(4), pp. 1149-1160.

Feldman, M. and Pentland, B., 2003. Reconceptualizing organisational routines as a source of flexibility. Administrative Science Quarterly, 48(1), pp.94-118

Fishbein, M. and Ajzen, I., 1975. Belief, attitude, intention and behavior an introduction to theory and research. Reading MA: Addison-Wesley.

Gallivan, M.J., 2001. Organisational adoption and assimilation of complex technological innovation: development and application of a new framework. The Data Base for Advances in Information Systems, 32, 32(3), pp.51-85.

Guba, E. and Lincoln, Y., 1989. Fourth generation evaluation. Beverly Hills: Sage Publications.

Gefen, D., Rigdon, E. and Straud, D., 2011. An update and extension to SEM guidelines for administrative and social science research. MIS Quarterly, 35(2), pp. iii-xiv.

Guillemette, M, Paré, G., 2012. Toward a new theory of the contribution of the IT function in organisations. MIS Quarterly, 36(2), pp. 529-551

Hair, J. F., Hult, G. T., Ringle, C.M. and Sarstedt, M., 2014. A primer on partial least squares structural equation modeling PLS-SEM. Thousand Oaks: Sage.

Hair, J. F., Ringle, C. M. and Sarstedt, M., 2011. PLS-SEM: indeed a silver bullet. The Journal of Marketing Theory and Practice, 19(2), pp. 139-152.

Horton, R., Buck, T., Waterson, P. and Clegg, C., 2001. Explaining intranet use with the technology acceptance model. Journal of Information Technology, 16(4), pp. 237-249.

Jarvis, C., MacKenzie, S. and Podsakoff, P., 2003. A critical review of construct indicators and measurement model misspecification in marketing and consumer research. Journal of Consumer Research, 30(2), pp. 199-218.

Kettinger, W. and Lee, C., 1997. Pragmatic perspectives on the measurement of Information Systems service quality. MIS Quarterly, 21(2), pp. 223-240.

Kim, G., Bongsik, S. and Kwon O., 2013. Investigating the value of sociomaterialism in conceptualizing IT capability of a firm. Journal of Management Information Systems, 29(3), pp.327-362

Klecun, E. and Cornford, T., 2003. An interpretative evaluation of a healthcare intranet. International Journal of Healthcare Technology and Management, 5(6), pp.407-421.

Kristensen, K. and Eskildsen, J., 2010. Design of PLS-based satisfaction studies, In: E. Esposito-Vinzi, W.W. Chin, J. Henseler and H. Wang. Eds. Handbook of Partial Least Squares, Berlin: Springer-Verlag, pp. 247-278.

Lee, S. and Kim, B. G., 2009. Factors affecting the usage of intranet: a confirmatory study. Computers in Human Behavior, 25(1), pp. 191-201.

Lohmöller, J.-B., 1989. Latent variable path modeling with partial least squares. Heidelberg: Physica-Verlag.

Marciniak, R., Geugnon, J.-F. and Elmael, M., 2012. Les facteurs de succès et les effets de l'intranet pédagogique dans trois écoles de management. AIM'2012, Bordeaux, pp. 1-22.

Marciniak, R., Geugnon, J.-F. and Jouini, N., 2009. Contribution des valeurs du système d'information à la performance organisationnelle. AIM'2009, Marrakech, pp. 1-14.

Marciniak, R. and Rowe, F., 2009. Systèmes d'information, dynamique et organisation. Paris: Economica. 
Marcoulides, G. and Saunders, C., 2006. PLS: a silver bullet? MIS Quarterly, 30(2), pp. iii-ix.

Mitra, S., Sambamurthy, V. and Westerman, G., 2011. Measuring IT performance and communicating value. MIS Quarterly Executive, 10(1), pp. 47-59.

Mosbey, R., Baile, S. and Zeribi, O., 2012. L'effet des facteurs contextuels, de la valeur perçue et de l'acceptation d'un intranet sur le succès de sa mise en œuvre: le cas d'une Organisation Bancaire Internationale. AIM'2012, Bordeaux, pp. 1-57.

Myerscough, M., 2002. Concerns about Servqual's underlying dimensions. Proceedings of 2002 International Association for Computer Information Systems Conference, pp. 1-9.

Nevo, S. and Wade, M., 2010. The formation and value of it-enabled resources: antecedents and consequences of synergistic relationships. MIS Quarterly, 34(1), pp.163-183.

Norzaidi, M., Salwani, M., Amato, S. and Rafidah, K., 2008. A study of intranet usage and resistance in Malaysia's port industry. Journal of Computer Information Systems, 49(1), pp. 37-47.

O'Muircheartaigh, C., Krosnick, J. and Helic, A., 2001. Middle alternatives, acquiescence, and the quality of questionnaire data. University of Chicago: Irving B. Harris Graduate School of Public Policy Studies.

Parasuraman, A., Zeithaml, V. and Berry, L., 1988. Servqual, a multiple-item scale for measuring customer perceptions of service quality. Journal of retailing, 64(1), pp. 12-40.

Petter, S., Delone, W. and McLean, E., 2008. Measuring information systems success: models, dimensions, measures and interrelationships. European Journal of Information Systems, 17(3), pp. 236-263.

Petter, S., Delone, W. and McLean, E., 2013. Information Systems success: the quest for the independent variables. Journal of Management Information Systems, 29(4), pp. 7-61.

Pitt, L., Watson, R. and Kavan, B., 1995. Service quality: a measure of Information Systems effectiveness. MIS Quarterly, 19(2), pp. 173-187.

Reinartz, W., Haenlein, M. and Henseler, J., 2009. An empirical comparison of the efficacy of covariance-based and variance-based SEM. International Journal of Research in Marketing, 26(4), pp. 332-344.

Ringle, C. M., Sarstedt, M. and Straub, D., 2012. A critical look at the use of PLS-SEM in MIS Quarterly. MIS Quarterly, 36(1), pp. iii-xiv.

Santhanam, R. and Hartono, E., 2003. Issues in linking Information Technology capability to firm performance. MIS Quarterly, 27(1), pp. 125-153.

Saunders, C. and Jones, J., 1992. Measuring performance of the Information Systems function. Journal of Management Information Systems, 8(4), pp. 63-82.

Saunders, A., and Brynjolfsson, E., 2016. Valuing information technology related intangible assets. Mis Quarterly, 40(1), pp. 83-110.

Saxena, D., and McDonagh, J., 2019. Evaluating ERP implementations: the case for a lifecycle-based interpretive approach. The Electronic Journal Information Systems Evaluation, 22(1), pp. 29-37

Tenenhaus, M., Amato, S. and Esposito Vinzi, V., 2004. A global Goodness-of-Fit index for PLS structural equation modelling. In Proceedings of the XLII SIS Scientific Meeting. The XIII SIS Scientific Meeting, 1(2), pp. 739-742.

Venkatesh, V. and Davis, F. 2000. A theoretical extension of the technology acceptance model: four longitudinal field studies. Management Science, 46(2), pp. 186-204.

Venkatesh, V., Morris, M. G., Davis, G. B., and Davis, F. D. 2003. User acceptance of information technology: Toward a unified view. MIS quarterly, 3(27), pp. 425-478.

Wataya, E., and Shaw, R. 2019. Measuring the value and the role of soft assets in smart city development. Cities, 94, 106-115.

Watson, R., Pitt, L. and Kavan, B., 1998. Measuring Information Systems service quality: lessons from two longitudinal case studies. MIS Quarterly, 22(1), pp. 61-79.

Wold, H., 1973. Nonlinear iterative partial least squares, NIPALS modelling: some current developments. In: P.R. Krishnaiah, 1973, Proceedings of the 3rd International Symposium on Multivariate Analysis, Dayton, pp. 383-407. 


\section{Appendices}

Appendix 1: Measurements models and constructs

\begin{tabular}{|c|c|c|c|}
\hline Construct & Sub-construct & Items & Name of items \\
\hline \multirow{14}{*}{$\begin{array}{l}\text { Perceived patrimonial value } \\
\text { of the intranet }\end{array}$} & \multirow{5}{*}{$\begin{array}{l}\text { Technical quality } \\
\text { (Reflective) }\end{array}$} & [intranet] is easy to use & Qtec1 \\
\hline & & Its response time is fast & Qtec2 \\
\hline & & We learn to use it quickly & Qtec3 \\
\hline & & Is friendly and attractive & Qtec4 \\
\hline & & Has good graphic quality & Qtec5 \\
\hline & \multirow{5}{*}{$\begin{array}{l}\text { Information quality } \\
\quad \text { (Reflective) }\end{array}$} & $\begin{array}{l}\text { [information on the intranet is] Reliable } \\
\text { (error free) }\end{array}$ & Qin1 \\
\hline & & Exhaustive (complete) & Qin2 \\
\hline & & Relevant (appropriate for work) & Qin3 \\
\hline & & Accurate & Qin4 \\
\hline & & Available (accessible) & Qin5 \\
\hline & \multirow{4}{*}{$\begin{array}{l}\text { Quality of service } \\
\text { (Reflective) }\end{array}$} & $\begin{array}{l}\text { Staff in charge of the intranet are } \\
\text { available to help users }\end{array}$ & Qser1 \\
\hline & & $\begin{array}{l}\text { In case of failure of the intranet the } \\
\text { interventions are fast }\end{array}$ & Qser2 \\
\hline & & The help desk is efficient & Qser3 \\
\hline & & $\begin{array}{l}\text { The quality of service associated with the } \\
\text { intranet is good in general }\end{array}$ & Qser4 \\
\hline \multirow{8}{*}{$\begin{array}{l}\text { Perceived use value of the } \\
\text { intranet }\end{array}$} & \multirow{5}{*}{$\begin{array}{l}\text { Collaboration } \\
\text { (Reflective) }\end{array}$} & $\begin{array}{l}\text { [Intranet site of the School of } \\
\text { Management allows] To work better in a } \\
\text { group }\end{array}$ & Vuco1 \\
\hline & & To work more in a group & Vuco2 \\
\hline & & $\begin{array}{l}\text { To have a better coordination with the } \\
\text { teachers of the school }\end{array}$ & Vuco3 \\
\hline & & $\begin{array}{l}\text { To have a better coordination with the } \\
\text { students of the school }\end{array}$ & Vuco4 \\
\hline & & $\begin{array}{l}\text { To have a better coordination with the } \\
\text { administrative staff of the school }\end{array}$ & Vuco5 \\
\hline & \multirow{3}{*}{$\begin{array}{l}\text { Learning } \\
\text { (Reflective) }\end{array}$} & To learn more easily & Vuap1 \\
\hline & & Learn more effectively & Vuap2 \\
\hline & & $\begin{array}{l}\text { In general, the intranet is useful as part } \\
\text { of my training at the school of } \\
\text { management }\end{array}$ & Vuap3 \\
\hline \multirow{4}{*}{ Organisational impact } & \multirow{4}{*}{$\begin{array}{c}\text { Organisational } \\
\text { impact (Reflective) }\end{array}$} & $\begin{array}{l}\text { Improves the overall quality of the } \\
\text { services offered by the school }\end{array}$ & Imporgani1 \\
\hline & & $\begin{array}{l}\text { Improve the overall efficiency of the } \\
\text { services offered by the school }\end{array}$ & Imporgani2 \\
\hline & & $\begin{array}{l}\text { Improves the overall speed of the } \\
\text { services offered by the School }\end{array}$ & Imporgani3 \\
\hline & & $\begin{array}{l}\text { Contributes in a general way to the } \\
\text { improvement of the organisational } \\
\text { performance of the school }\end{array}$ & Imporgani4 \\
\hline Success of the intranet & $\begin{array}{l}\text { Success of the } \\
\text { intranet } \\
\text { (Reflective) }\end{array}$ & Overall rating of the intranet site & Nintranet \\
\hline & & & \\
\hline
\end{tabular}


Appendix 2: Descriptive statistics on the 3 school's samples

\begin{tabular}{|c|c|c|c|c|}
\hline \multicolumn{5}{|c|}{ Descriptive statistics on the 3 schools samples } \\
\hline & $\begin{array}{l}\text { School A } \\
n=107\end{array}$ & $\begin{array}{l}\text { School B } \\
n=348\end{array}$ & $\begin{array}{l}\text { School C } \\
n=101\end{array}$ & \\
\hline Bachelor $3^{\text {rd }}$ year & 8.41 & $27.59 *$ & 72.28 & \multirow{6}{*}{ in $\%$} \\
\hline Master $1^{\text {st }}$ year & 34.58 & \multirow{2}{*}{$16.67^{* *}$} & \multirow{2}{*}{$\begin{array}{r}25.74 \\
1.98 \\
\end{array}$} & \\
\hline Master $2^{\text {nd }}$ year & 57.01 & & & \\
\hline Engineer & NC & 12.93 & NC & \\
\hline Certification & NC & 27.87 & $\mathrm{NC}$ & \\
\hline Others & NC & 14.94 & $\mathrm{NC}$ & \\
\hline Mean of use & 1.94 & 2.14 & 1.97 & 4 modalities \\
\hline Mean intranet availability & 5.36 & 5.35 & 5.07 & 6 modalities \\
\hline Use homework deposit & 66.36 & 32.47 & 11.88 & \\
\hline Deposit of exercises & 40.19 & 35.92 & 30.69 & \\
\hline Download research article & 25.23 & 24.87 & 19.80 & \\
\hline Consultating list of units & NA & 54.31 & 12.87 & \\
\hline Consultating the planning & NA & 78.45 & 95.05 & \\
\hline Consultation of exam schedule & NA & 77.01 & 58.42 & in \% \\
\hline Curriculum Consultation & NA & 77.30 & 36.63 & \\
\hline Communication with students/teachers & NA & 64.94 & 29.70 & \\
\hline Download press & 15.89 & NA & NA & \\
\hline Download bibliography & 30.84 & NA & NA & \\
\hline Webography & 14.02 & NA & NA & \\
\hline
\end{tabular}

\begin{tabular}{|l|l|l|l|l|}
\hline Quality of service, don't know responses & Number of items \\
\hline & $\begin{array}{l}\text { School A } \\
\mathrm{n}=107\end{array}$ & $\begin{array}{l}\text { School B } \\
\mathrm{n}=348\end{array}$ & $\begin{array}{l}\text { School C } \\
\mathrm{n}=101\end{array}$ & 5 to 5 \\
\hline Technical quality & 0 to 3 & 5 to 18 & 3 to 7 & 5 \\
\hline Information quality & 0 to 4 & 15 to 53 & 42 to 58 & 5 \\
\hline Quality of service & 45 to 62 & 173 to 217 & 12 to 15 & 4 \\
\hline $\begin{array}{l}\text { Organisational } \\
\text { contribution }\end{array}$ & 7 to 14 & 41 to 52 & 4 \\
\hline
\end{tabular}

